Jurnal Ilmu Dan Teknologi Kesehatan

Vol 8, No 2, March 2021,

ISSN: 2338-9095 (Print)

ISSN: 2338-9109 (online)

\title{
Differences of Fruit-Vegetable Consumption, Blood Pressure In Highland And Lowland
}

\author{
Afriyana Siregar, Arie Krisnasary, Demsa Simbolon \\ Poltekkes Kemenkes Bengkulu, Indonesia \\ Email: Afriyanasiregar@gmail.com
}

\author{
Article history \\ Posted, June 15th, 2020 \\ Reviewed, Jan 22nd, 2021 \\ Received, March 5th, 2021
}

\begin{abstract}
Consumption of vegetables and fruit daily can prevent degenerative diseases such as coronary heart disease, stroke, and cancer. One of the causes is unstable blood pressure. This study aimed to determine the differences in the consumption of vegetables, fruit, and blood pressure in highland (mountains) and lowland (coastal) communities in Bengkulu. This research was observational analytic with a cross-sectional approach. A sample of 65 people in the highlands (Kepahiang) and 65 people on the coast (Pasar Ikan) was purposive sampling. Statistical test using independent t-test. This study indicates that the average consumption of vegetables in the highlands is 170.33 grams/day, and fruit consumption is 100.96 grams/day. In comparison, the consumption of vegetables in the lowlands is 165.65 grams/day. Moreover, fruit consumption in the lowlands is 187.26 grams/day. In the highlands, the mean systolic blood pressure was $134.72 \mathrm{mmHg}$, and the diastolic was 83.18 $\mathrm{mmHg}$, while the mean systolic blood pressure was $126.62 \mathrm{mmHg}$, and the diastolic 75.71 $\mathrm{mmHg}$. This study concludes that there is no difference between vegetable consumption in the highlands and the lowlands, but there are differences in fruit consumptionand systolic diastolic blood pressure in the highlands and the lowlands. In health services, the existing Gerakan Masyarakat Hidup Sehat (GERMAS) program should be promoted.
\end{abstract}

Keywords: blood pressure; fruit; lowland; plateau; vegetables

\begin{abstract}
ABSTRAK
Konsumsi sayur dan buah setiap hari dapat mencegah penyakit degeneratif seperti jantung koroner, stroke dan kanker. Salah satu penyebabnya adalah tekanan darah yang tidak normal. Tujuan penelitian ini untuk mengetahui perbedaan konsumsi sayur, buah dan tekanan darah pada masyarakat di dataran tinggi (pegunungan) dengan dataran rendah (pantai) di Bengkulu. Penelitian ini merupakan penelitian observasional analitik dengan pendekatan cross sectional. Sampel sebanyak 65 orang yang tinggal di dataran tinggi (Kepahiang) dan 65 orang yang tinggal di pesisir pantai (pasar Ikan) yang diambil secara purposive sampling. Uji statistik menggunakan uji t-independen. Hasil Penelitian menunjukkan bahwa rata- rata konsumsi sayur di dataran tinggi adalah 170,33 gram/ hari, sedangkan rata-rata konsumsi sayur di dataran rendah adalah 165,65 gram/ hari. Rata-rata konsumsi buah di dataran tinggi adalah 100,96 gram/ hari, sedangkan rata-rata konsumsi buah di dataran rendah adalah 187,26
\end{abstract}


gram/hari. Rata-rata tekanan darah sitolik di dataran tinggi adalah $134,72 \mathrm{mmHg}$ dan di dataran rendah adalah 126,62 $\mathrm{mmHg}$. Rata-rata tekanan darah diastolik di dataran tinggi adalah $83,18 \mathrm{mmHg}$ dan di dataran rendah adalah $75,71 \mathrm{mmHg}$. Kesimpulan penelitian ini yaitu tidak ada perbedaan antara konsumsi sayur di dataran tinggi dan dataran rendah, tetapi ada perbedaan konsumsi buah dan tekanan darah sistolik dan diastolik di dataran tinggi dan dataran rendah. Gerakan Masyarakat Hidup Sehat (GERMAS) perlu ditingkatkan.

Kata Kunci: sayur; buah; tekanan darah; dataran tinggi; dataran rendah

\section{INTRODUCTION}

WHO generally recommended consuming vegetables and fruits for a healthy life of 400 grams per person per day, consisting of 250 grams of vegetables and 150 grams of fruit. In general, the Indonesian population consumes more vegetables, namely $94.8 \%$, compared to fruit, which is only $33.2 \%$. The age group of the population who consumed the most miniature vegetables were children under five (0-59 months), namely $86.2 \%$, and those who consumed the most vegetables were adults (19-55 years), namely $95.8 \%$. (Hermina, 2016). In 2016, consumption of fruits and vegetables in Indonesia was less than half of the recommended consumption. Most of the Indonesian population consumes 173 grams of fruit and vegetables per day, which is less than the recommended dietary allowance (RDA). Consumption of fruit was minor than consuming vegetables, namely 67 grams, while vegetables were 107 grams per capita per day. Furthermore, not all Indonesians consume fruit and vegetables, with $97.3 \%$ consuming vegetables and
$73.6 \%$ consuming fruit in 2016 . Consumption of fruits and vegetables has shown a declining trend over the past five years. Fruit consumption has decreased slightly, by $3.5 \%$, while vegetable consumption has decreased by $5.3 \%$ (WFP, 2017).

In Bengkulu Province, the average portion of vegetable consumption in the Kepahiang Regency was 1.6, while the average consumption of fruit is mostly in Bengkulu City was 0.6. Based on the age group, the Bengkulu Province population who consumed the most vegetables was the 45-49 year old and 60-64 age group, namely 1.3 , while the fruit consumption in each age group was almost the same, that is 0.4 (Balitbangkes, 2013). Consumption of vegetables and fruit every day is essential for health. Consumption of vegetables and fruit daily can prevent degenerative diseases such as coronary heart disease, stroke, and cancer (WHO, 2012). 
One of the causes of degenerative diseases is unstable blood pressure. The results of blood pressure measurements include hypertension and hypotension. Hypertension is a common disease and causes death due to stroke and is a trigger factor of myocardial infarction (Debora, 2011).

Geographical location influences blood pressure. That is, lowland have a higher risk of developing hypertension than in highland. This is due to the difference in altitude affects physiology related to gravity. Also, several studies on hypertension in coastal areas are associated with the lifestyle of people who often consume salt and water that contain lots of sodium compared to the lifestyle of highland people who often consume more vegetables and fruits. (Mandang, 2015). Hypoxia exposure at high altitudes is known as a risk factor for hypertension. However, studies that examined the relationship between height and hypertension are rare (Mingji et al., 2015). Based on the results of research in Tomohon, Manado City on the comparison of blood pressure between the population living in the highlands and the lowlands with 160 samples, showed that the number of people with $75 \%$ normal systolic and
72.5\% diastolic blood pressure was more in the highlands compared to the lowlands. $55 \%$ and $36.25 \%$, respectively. More hypertension was found with systolic at $45 \%$ and diastolic at $63.75 \%$ in the lowlands than the highlands, respectively, $25 \%$ and $27.5 \%$ (Sukarno, 2014).

Kepahiang Regency consists of 8 Districts with 14 Public Health Centers (Puskesmas) of the 14 existing Puskesmas, Cugung Lalang including those that had a high incidence of hypertension, that is 90.97\%. (Dinas Kesehatan Kepahiang, 2016). Based on the profile of the Bengkulu City Health Office in 2016, the highest incidence of hypertension were at Puskesmas Pasar Ikan, Puskesmas Lingkar Timur and Puskesmas Basuki Rahmad. (Dinas Kesehatan Kota Bengkulu, 2016).

Based on the initial survey results by using the semi qualitative FFQ form (Food Frequency Questionnaire) in the working area of the Cugung Lalang Puskesmas, it was found that all $10(100 \%)$ samples were eaten fewer vegetables than the WHO recommended. The fruit consumption data obtained, six people $(60 \%)$ consumed less fruit than WHO recommended. There were five people $(50 \%)$ who had low systolic 
blood pressure (SBP), two people (20\%) normal, and three people (30\%) were high. While the diastolic blood pressure, there were eight people $(80 \%)$ who had low diastolic blood pressure, one person (10\%) normal, and one person (10\%) was high. A preliminary survey in the lowlands of 10 respondents indicated that $90 \%$ (9 people) had blood pressure above normal. The present study aimed to evaluate the differences in fruit and vegetable consumption and blood pressure in highland and lowland.

\section{METHOD}

This study was an observational study with a cross-sectional design. The study population was all male and female adults with systolic blood pressure greater than $120 \mathrm{mmHg}$ and diastolic blood pressure more than $80 \mathrm{mmHg}$. Systolic blood pressure was $120 \mathrm{mmHg}$, and diastolic blood pressure was $80 \mathrm{mmHg}$ which was selected from a visit to Puskesmas Cugung Lalang, Kepahiang Regency (highland), and Pasar Ikan Kota Bengkulu (lowland).

The inclusion criteria were willingness to be a respondent. The sample was 19-64 years old and did not have kidney disease, diabetes, hormonal disorders, and not pregnancy. The sampling technique was purposive sampling with a sample of 65 people in each place.
The research was conducted in July September 2018 in the work area of the Puskesmas Cugung Lalang, Kepahiang Regency and Puskesmas Pasar Ikan in Bengkulu City.

Secondary data were the respondent's identity obtained from the results of annual reports from the Puskesmas, the Health Office, and other relevant institutions. Primary data was collected using a semiqualitative FFQ (Food Frequency Questionnaire) form assisted by a Household Size Book (URT), a food model, or food photos to measured the consumption of vegetables and fruit for the past one (1) month. Blood pressure was measured with the Omron blood pressure monitor. Data analysis used univariate analysis to describe the consumption of fruit, vegetables, and blood pressure in the highland and lowland. Bivariate analysis using an independent t-test to determine differences in consumption of vegetables, fruit, and blood pressure.

\section{RESULTS AND DISCUSSION}

This research was conducted in highland and lowland communities in the working area of the Cugung Lalang Community Health Center and Pasar Ikan Public Health Center (Puskesmas), aged 19-64 years, who met the inclusion criteria. Adult respondents were taken because the 
age group consumes the most vegetables based on Balitbangkes data. The number of respondents in this study was 65 people each.
Characteristics of respondents in this study discussed age, gender, and occupation.

Table 1. Frequency Distribution of Respondents Characteristics in the Highland

\begin{tabular}{lll}
\hline $\begin{array}{c}\text { Characteristics of } \\
\text { Respondents }\end{array}$ & n & \% \\
\hline Age & 5 & $7,7 \%$ \\
$19-29$ y & 35 & $53,8 \%$ \\
$30-49$ y & 25 & $38,5 \%$ \\
\hline $50-64$ y & 3 & $4,6 \%$ \\
\hline Sex & 62 & $95,4 \%$ \\
$\quad$ Male & & \\
$\quad$ Female & 44 & $67,7 \%$ \\
\hline Occupation & 18 & $27,7 \%$ \\
$\quad$ Farmer & 3 & $4,6 \%$ \\
$\quad$ Housewife &
\end{tabular}

Based on table 1 above, it can be seen that the respondents are primarily between 30 49 years old, and the sex is primarily female at $53.8 \%$. Most of the respondents' occupations are farmers, $67.7 \%$. This result is in line with Adriani's opinion (2012), which states that the body is in a peak state of physical ability and has decreased function. This condition can make some people fall asleep and start making bad habits that can affect future health and degenerative diseases. The sex of most of the women was $95.4 \%$, and a small proportion of them was male by 4.6. 
Table 2. Frequency Distribution of Respondents Characteristics in the Lowland

\begin{tabular}{lll}
\hline \multicolumn{1}{c}{$\begin{array}{c}\text { Characteristics of } \\
\text { Respondents }\end{array}$} & $\mathbf{n}$ & $\%$ \\
\hline Age group & 4 & \\
$19-29$ y & 29 & $4,2 \%$ \\
$30-49$ y & 32 & $49,6 \%$ \\
$50-64$ y & & \\
Sex & 15 & $23,0 \%$ \\
Male & 50 & $77,0 \%$ \\
Female & & \\
Occupation & 46 & $70,8 \%$ \\
Housewife & 8 & $7,3 \%$ \\
Entrepreneur & 5 & 7,7 \\
Fisherman & 5 & 1,5 \\
Traders & 1 & \\
Retired & & \\
\hline
\end{tabular}

Based on table 2, it can be seen that the respondents are primarily between 30-49 years old, and the sex is primarily female (44.6\%). Respondents were almost part of a housewife at $70.8 \%$. Most of the samples were women, which is $77.0 \%$, and a small proportion was male by $23 \%$.

The distribution of the respondents' vegetable consumption in highland and lowland areas can be seen in table 3 .

Table 3. Distribution of vegetable consumption in highland and lowland

\begin{tabular}{lccc}
\hline \multicolumn{1}{c}{ Variable } & N & $\begin{array}{c}\text { Percentage } \\
(\mathbf{\%})\end{array}$ & Mean \pm SD \\
\hline $\begin{array}{l}\text { Vegetable consumption in Local Communities } \\
\text { Highland }\end{array}$ & & \\
Adequate & 15 & 23,07 & $168,97 \pm 88,92$ \\
Inadequate & 50 & 76,93 & \\
& & & \\
Vegetable consumption in Local Communities & & & \\
lowland & & & \\
Adequate & 13 & 20,00 & $151,06 \pm 114,56$ \\
Inadequate & 52 & 80,00 & \\
& & & \\
\hline
\end{tabular}

Based on table 3 above, the results showed that the average vegetable consumption of respondents in the highlands was 168.97 grams. The average consumption of vegetables in respondents in the lowlands was 151.06 grams. The average consumption of vegetables recommended by the Ministry of Health (2014) is $\geq 250 \mathrm{~g}$ / day. It means that, on average, respondents in the highlands and the lowlands consumed fewer vegetables. This 
result is in line with the Bengkulu Basic Health Research report (Riskesdas 2007), which states that the overall population aged $>10$ years consume fewer vegetables and fruit, $92.1 \%$. This is also in line with the results of the 2013 Riskesdas showing that $93.6 \%$ of Indonesians consume less fiber from vegetables and fruit.

According to the National Total Diet Study (SDT) results, the vegetable consumption of the Indonesian population is still low, namely 57.1 grams /day. The results in the highlands found that most of the respondents consumed vegetables in a bit of portion. It was because some people did not like vegetables. The types of vegetables consumed by respondents come from their crops, sometimes given by neighbors, but several types of vegetables are bought in the nearest market or on market days in the area. Types of vegetables usually obtained from planting or given by neighbors such as cassava leaves, luffa, green beans, sweet leaves, long beans, chayote, cucumber, Lumai shoots, green mustard, and eggplant. The types of vegetables consumed by respondents are cucumbers, tomatoes, shoots of lumai, round green eggplant, carrots, kale, long eggplant, cassava leaves, beans, and bean sprouts. On average, respondents consumed vegetables in one meal, which is only 2-3 tablespoons or about 20-30 grams. So, in one day, the respondents' average vegetable consumption is only 60-90 grams. The results in the lowlands showed that almost all respondents ate a bit of vegetable. Lack of vegetable consumption among respondents in the lowlands is caused by people who consumed more foods derived from animal foods such as fish from the sea because most people in the lowlands consume fish almost every day compared to vegetables. People usually consumed vegetables from nearby markets, and some people sometimes buy vegetables that have been cooked at food stalls. Types of vegetables commonly consumed by people in the lowlands are spinach, kale, mustard greens, cassava leaves, watercress, tomatoes, carrots, green beans, long beans, cabbage, luffa, round green eggplant, and purple eggplant.

Some respondents ate certain vegetables such as kale and spinach in one meal, 1-2 tablespoons of vegetables or about 15-30 grams.

The distribution of the respondents' fruit consumption in highland and lowland areas can be seen in table 4 . 
Table 4. Distribution of Fruit Consumption in highland and lowland

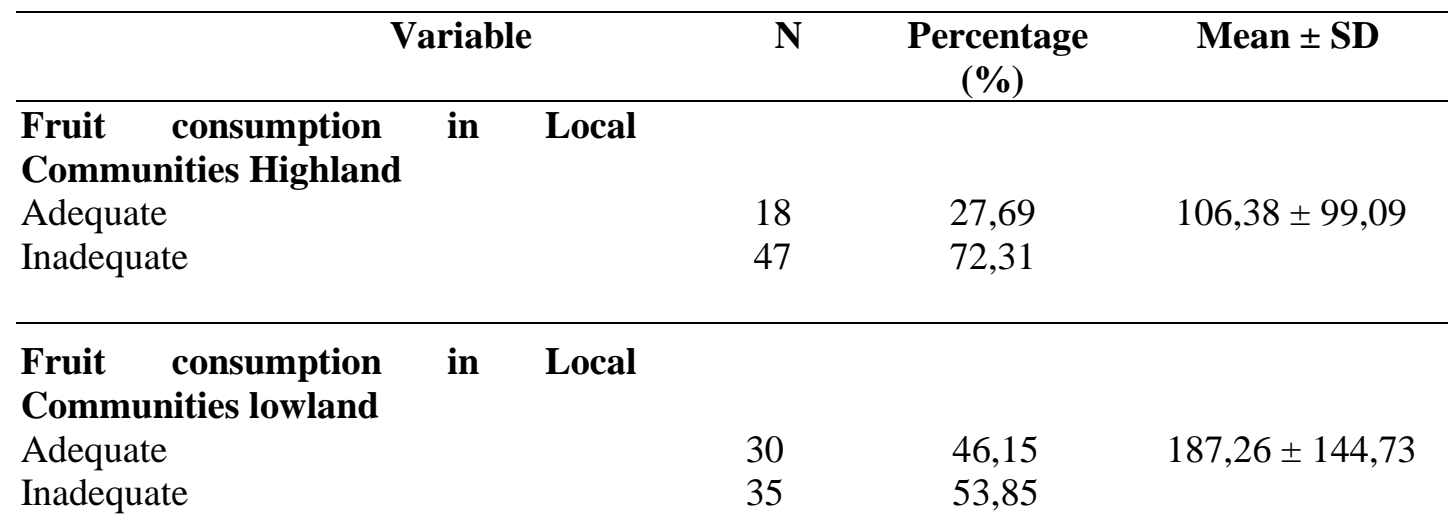

Based on table 4 above, it is found that the average fruit consumption of respondents in the highlands was 106.38 grams, and the average fruit consumption of respondents in the lowlands was 187.26 grams. The average fruit consumption recommended by the Ministry of Health (2014) is> 150 grams/day. The average respondents in the highlands consumed a bit of fruit, while in the lowlands, the average respondents consumed adequate fruit. This result was in line with the Bengkulu Riskesdas report (2007), which stated that overall the population aged ten years and over consumes fewer vegetables and fruit, 92.1\%. This was also in line with Riskesdas's (2013) results, showing that $93.6 \%$ of Indonesians consumed less fiber from vegetables and fruits. According to the National Total Diet Study results, fruit consumption is only 33.5 grams/day.
The results in the highlands found that most of the respondents consumed a bit of fruit. The fruit consumed by respondents on average was purchased in markets that were quite far from they lived. However, there were some fruits that they usually bought at the nearest market that only had it once a week, such as oranges and sapodilla. Several fruits were also harvested by respondents in their farms, such as papaya, banana, guava, and rose apple. The types of fruit most consumed by respondents were sweet oranges, papayas, and Ambon bananas. Respondents only consumed fruit at most two times a week in portions that were not much, namely only one fruit.

The results in the lowlands showed that most of the respondents ate a bit of fruit. Low fruit consumption among respondents in the lowlands was caused by people not 
used to stored fruit at home. Respondents also rarely buy fruit at the nearest market, but respondents often bought the fruit from fruit sellers who walked around. Types of fruit commonly consumed by respondents include oranges, Ambon bananas, lemongrass bananas, papaya, watermelon, yam bean, and pineapple. Respondents most frequently consumed papaya, sweet orange, and Ambon banana. Some respondents grew papaya fruit plants themselves at home, so it was easy to consume. In contrast, other fruits such as watermelon, yam, and pineapple, respondents rarely consumed because respondents usually bought them indirectly from markets or stalls but buy them from fruit traders or rujak traders who go around were sold in pieces. The respondent did not buy the fruit every day.

Respondents often consumed sweet orange and ambon bananas 2-3 times a week, with the portion size eaten was 1-2 pieces, while the papaya fruit usually 3-4 times a week with the portion size eaten is 2-3 medium pieces. So, the respondents' fruit consumption in a day was around 100-150 $\mathrm{g} /$ day. It can be seen that the fruit consumption of the respondents in the working area of the Pasar Ikan Puskesmas was sufficient and by the recommendations, namely $\geq 150 \mathrm{~g} /$ day

(Ministry of Health, 2014).

Based on BPS data, the consumption of fruit and vegetables in the last five years has decreased, the current consumption level was less than half the recommended consumption level. Although fruit and vegetable production is abundant, the Indonesian population's consumption of fruits and vegetables was inadequate (WFP, 2017). Data from the Indonesia World Food Program (WFP) in the category of fruit and vegetables, the projected highest demand for food consumption per capita was apples, with an increase from $55 \%$ in 2025 to $1.49 \mathrm{~kg}$ per capita per year, and $73.5 \%$ in 2045 to $1.66 \mathrm{~kg}$ per capita per year. Apple consumers were mainly from the urban population in high and middle-income groups. Demand for local fruits such as oranges, bananas, malacca, and mangoes was projected to not be as high in 2025 and 2045 as apples, and this demand was dominated by imported apples (Arifin, 2018).

The distribution of the respondents' blood pressure in the highland and lowland areas can be seen in table 5 . 
Table 5. Overview of Systolic and Diastolic Blood Pressure in the Highlands and Lowlands

\begin{tabular}{|c|c|c|c|c|}
\hline \multirow{2}{*}{ Variable } & \multicolumn{2}{|c|}{ Highland } & \multicolumn{2}{|c|}{ Lowland } \\
\hline & $\mathbf{N}$ & $\%$ & $\mathbf{N}$ & $\%$ \\
\hline \multicolumn{5}{|l|}{ Systolic Blood Pressure } \\
\hline Normal & 19 & 29,93 & 20 & 30,77 \\
\hline Pre- Hypertension & 24 & 36,92 & 26 & 40 \\
\hline Hypertension stage 1 & 12 & 18,46 & 15 & 23,07 \\
\hline Hypertension stage 2 & 10 & 14,69 & 4 & 6,16 \\
\hline \multicolumn{5}{|c|}{ Diastolic Blood Pressure } \\
\hline Normal & 25 & 38,46 & 29 & 44,61 \\
\hline Pre- Hypertension & 24 & 36,92 & 28 & 43,07 \\
\hline Hypertension stage 1 & 10 & 15,38 & 5 & 7,69 \\
\hline Hypertension stage 2 & 6 & 9,24 & 3 & 4,63 \\
\hline Total & 65 & 100 & 65 & 100 \\
\hline
\end{tabular}

Based on JNC-8 (Joint National

Committee-8, Guidelines on hypertension), the classification of blood pressure in adults aged $>18$ years was divided into 4 (four) categories, as seen from the patient's systolic and diastolic blood pressure. These categories were normal blood pressure if the systolic blood pressure is $<120 \mathrm{mmHg}$ and diastolic <80 $\mathrm{mmHg}$ ); pre-hypertension, if the systolic blood pressure is $120-139 \mathrm{mmHg}$ and diastolic 80-89); hypertension stage 1 , if the systolic blood pressure is $140-159$ and the diastolic is 90-99; and stage 2 hypertension, if the systolic blood pressure is $\geq 160 \mathrm{mmHg}$ and diastolic $\geq 100 \mathrm{mmHg}$ (Bell, Kayce,
2015). Table 5 showed that almost half of the respondents have normal systolic blood pressure, nineteen people $(29.93 \%)$ in the highlands and the lowlands as many as 20 people $(30.77 \%)$. A small proportion of highlands and lowlands respondents experienced high systolic blood pressure (hypertension stages 1 and 2). Almost half of the respondents in the highlands and lowlands had normal diastolic blood pressure, namely $38.46 \%$ (25 people) and $44.61 \%$ (29 people), respectively. Only a small proportion of respondents, both in the highlands and those in the lowlands, had high diastolic blood pressure (hypertension stages 1 and 2) 
A. Siregar, A. Krisnasary, D. Simbolon, Differences of Fruit-Vegetable 168

Consumption, Blood Pressure In Highland And Lowland

Table 6. Mean Systolic and Diastolic Blood Pressure in the Highlands and Lowlands

\begin{tabular}{ccccc}
\hline \multirow{2}{*}{ Variable } & \multicolumn{2}{c}{ Highland } & Lowland \\
\cline { 2 - 5 } & Min-Max & Mean \pm SD & Min-Max & Mean \pm SD \\
\hline Systolic Blood Pressure & $97-203$ & $134,72 \pm 23,01$ & $90-170$ & $126,62 \pm 20,07$ \\
\hline Diastolic Blood Pressure & $56-123$ & $83,18 \pm 13,09$ & $60-101$ & $75,71 \pm 10,31$ \\
\hline
\end{tabular}

Table 6 showed that respondents' average systolic blood pressure in highland areas was $134.72 \mathrm{mmHg}$ and diastolic blood pressure was $83.18 \mathrm{mmHg}$. In comparison, respondents' systolic blood pressure in lowland areas was $126.62 \mathrm{mmHg}$ and diastolic blood pressure. $75.71 \mathrm{mmHg}$.

The study results found that respondents in the highlands had high systolic and diastolic blood pressures (prehypertension). The same as respondents in lowland areas whose systolic blood pressure was in the pre-hypertensive position, while diastolic blood pressure was at normal limits.

This study's results were in line with research in Tomohon, Manado, which shows that the number of people with a normal systolic blood pressure of $75 \%$ and diastolic $72.5 \%$ was more in the highlands compared to the lowlands, respectively 55\% and 36.25\%. (Sukarno, Inka, 2014).

The prevalence of hypertension in Indonesia according to the 2013 Riskesdas was $26.5 \%$. According to the 2007 Bengkulu Riskesdas, the prevalence of hypertension in Bengkulu was $21.6 \%$. According to data from the Kepahiang District Health Office, the proportion of hypertension in the Kepahiang Regency was $22.9 \%$.

The differences in vegetable and fruit consumption in the highlands and lowlands can be seen in table 7 and table 8.

Table 7 shows that statistical tests of vegetable consumption in the highlands and lowlands were 0.321 (p-value > 0.005) implied that there was no difference in vegetable consumption in the highlands and lowlands. In contrast, the MannWhitney results showed that fruit consumption in the highlands and lowlands was 0.000 (p-value $<0.005$ ), which means that there was a difference in fruit consumption in the highlands and lowlands. 
Table 7. Differences in Vegetable and Fruit Consumption in the Highlands and Lowlands

\begin{tabular}{cccccc}
\hline Variable & Groups & N & SD & Mean & p-value \\
\hline Vegetables & Highland & 65 & 88,9 & 168,97 & 0,321 \\
& Lowland & 65 & 114,52 & 151,06 & \\
\cline { 2 - 6 } Fruits & Highland & 65 & 99,09 & 106,38 & 0,000 \\
& Lowland & 65 & 144,73 & 187,26 & \\
\hline
\end{tabular}

The results showed that the average consumption of vegetables in the highlands was 168.97 grams/day, while the average consumption of vegetables in the lowlands was 151.06 grams/day. The results also showed that the average fruit consumption in the highlands was 100.38 grams/day, while the average fruit consumption in the lowlands was 187.26 grams/day. Vegetables and fruit are essential elements for a healthy diet. The benefits of consuming fruits and vegetables every day for body health are given the high content of various vitamins and minerals and fiber in fruits and vegetables. If consumed in the recommended portions, consumption of fruits and vegetables can reduce the risk of micronutrient deficiencies and attacks from non-communicable diseases. Inadequate consumption of fruits and vegetables was the 10th leading cause of the risk of death in the world (WFP, 2017). In rural and urban areas, Indonesians were pure consumers (net buyers) of fruit and vegetables. In 2016, an average of $82.9 \%$ of vegetables and $76.3 \%$ of fruit consumed came from purchased. Consumption of vegetables from self-production for the urban population was $6.4 \%$, while it was $27 \%$ in rural areas. On the other hand, consumption from self-production was slightly higher for fruit than for vegetables. $3.4 \%$ of fruit consumed by Indonesians in urban areas comes from their production, while residents in rural areas produce almost half of the fruit they consumed. (40\%) (WFP, 2017).

This study's results were in line with the results of SDT 2014, which stated that mountainous areas were usually included in rural areas where the average population works as farmers, while coastal areas were included in urban areas where the average population works as fishermen. When viewed from the residence area, the proportion of the population who consume vegetables was almost the same between urban and rural areas (94.8\%). However, the proportion of the population who consume fruit appears to be higher in urban areas (35.9\%) than in rural areas (30.5\%). (Hermina, 2016) 
Kepahiang Regency, a highland area and consists of many villages, is dominated by a primarily farmers population. In contrast, the Fish Market area, which is close to the capital city of Bengkulu Province, is an area where the population mainly works as fishermen.

The difference in vegetable consumption in the highlands and the lowlands can be seen in table 8.

Table 8. Differences in Systolic and Diastolic Blood Pressure in the Highlands and Lowlands

\begin{tabular}{clcccc}
\hline Variable & Groups & N & SD & Mean & p-value \\
\hline Systolic Blood Pressure & Highland & 65 & 23,01 & 134,72 & 0,034 \\
& Lowland & 65 & 20,07 & 126,62 & \\
\cline { 3 - 5 } Diastolic Blood Pressure & Highland & 65 & 13,09 & 83,18 & 0,000 \\
& Lowland & 65 & 10,31 & 75,71 & \\
\hline
\end{tabular}

Table 8 showed the Mann-Whitney Test results for systolic blood pressure in the highlands and the lowlands was 0.034 (pvalue > 0.005), implied that there was a difference between systolic blood pressure in the highlands and lowlands. While the results diastolic blood pressure was 0.000 (p value> 0.005), there was a difference between the diastolic blood pressure in the highlands and the lowlands. The results showed that the average systolic blood pressure in the highlands and lowlands was in a pre-hypertensive condition. The average diastolic blood pressure in the highlands also shows a pre-hypertensive condition, while the average diastolic blood pressure in the lowlands was still in normal conditions.

This result was similar to research conducted in Manado, with 160 samples of the population living in the highlands of the
Rurukan Village, Tomohon City, and the lowlands of the Malalayang Village, Manado City, showed significant differences in blood pressure measurements between the population living in the highlands and the lowlands. Normal systolic blood pressure $(75 \%)$ is higher in the highlands than in the lowlands (55\%) (Sukarno, 2014).

This result was different from research on hypertension in coastal areas associated with the lifestyle of people who often consume salt and water that contain lots of sodium compared to the lifestyle of mountain people who often consume more vegetables and fruits (Mandang, 2015). Rusliafa's research (2014) which was conducted in Poasia Village representing coastal areas and Gunung Jati Village representing mountainous areas, showed 
that hypertension was more in coastal areas $(64.44 \%)$ compared to the mountainous region $(22,72 \%)$. The cross-sectional study results in Tibet indicate a significant correlation between elevation and prevalence of hypertension among the Tibet population. The socioeconomic status of the population can affect hypertension awareness and management. Very little hypertension research has been carried out in other Tibetan prefectures, where it is much higher (Mingji et al., 2015).

The results showed that the highlands' average systolic and diastolic blood pressure was higher than in the lowlands. These results were in line with evidence from previous studies, which also show an increased prevalence of hypertension at altitude, possibly due to greater stimulation of the chemoreceptor reflex in individuals with borderline hypertension (Mingji et al., 2015). Alifariki's research (2015) result showed that respondents who live in mountainous areas (104 people) are more likely to had hypertension (53\%) than those who lived in coastal areas (178 people) as many as $41 \%$. In this study, it was found that 65 people living in mountainous areas $(36.5 \%)$ had a habit of consuming salted fish because it is difficult to get fresh fish, and it is more durable because it is preserved.
The same reason was also expressed by respondents who live in the highlands (Kepahiang) who said they often consume salted fish, which is abundant in Bengkulu Province because it was difficult to get fresh fish. The people of Kepahiang had to go down the mountain first to get fresh fish. Apart from salted fish, people in Kepahiang were also accustomed to consuming salted eggs, anchovies, salted squid, and preserved vegetables.

\section{CONCLUSION}

The consumption of vegetables \& fruit in the highlands and the lowlands were still below the recommended daily consumption. Systolic blood pressure in the highlands and the lowlands were in a condition of prehypertension, only diastolic blood pressure in the highlands had pre-hypertension, while in the lowlands were in normal condition. There was no difference in vegetable consumption in the highlands and lowlands, and there was a difference in fruit consumption in the highlands and lowlands. There were differences in systolic and diastolic blood pressure in highlands and lowlands. This study did not explore confounding variables such as nutritional status, total sodium, and potassium intake. This present study did not differentiate between the processing of vegetables and fruit that respondents consumed, affecting 
the respondents' daily sodium intake. Future studies can examine other variables that affect adult blood pressure, including sodium, potassium and fat, nutritional status, and physical activity. In health services, the existing Gerakan Masyarakat Hidup Sehat (GERMAS) program should be promoted because some people do not understand the importance of fruit and vegetable consumption for health.

\section{ACKNOWLEDGMENT}

This research would not have been possible without the financial support of the Poltekkes Kemenkes Bengkulu. We are grateful to all of those we have had the pleasure to work with during this project.

\section{REFERENCES}

Adriani, Merryana, dkk. (2012). Peranan Gizi dalam Siklus Kehidupan. Jakarta : Kencana

Alifariki, L. O. (2015). Analisis Faktor Determinan Proksi Kejadian Hipertensi di Poliklinik Interna BLUD RSU Provinsi Sulawesi Tenggara. Medula, 3(1), 214-223.

Arifin, B. (2018). Modeling the Future of Indonesian Food Consumption: Modeling the Future of Indonesian Food Consumption. Final Report. Research Report submitted to the National Development Planning Agency (Bappenas), World Food Programme (WFP), and Food and Agricultural Organization of the
United Nations (FAO), Jakarta, June 2018.

Balitbangkes. (2013). Riskesdas dalam Angka Provinsi Bengkulu 2013. Jakarta: Kementerian Kesehatan RI.

Bell, K. et al. (2018). Hypertension: The Silent Killer: Updated JNC-8 Guideline Recommendations. www.APARX.org.

Debora, Oda. (2011). Proses Keperawatan dan Pemeriksaan Fisik. Jakarta : Penerbit Salemba Medika

Departemen Kesehatan RI. (2008). Laporan Hasil RISKESDAS Provinsi Bengkulu Tahun 2007.

Dewantari, N. M. (2011). Fruits And Vegetables Consumption Pattern In School Children. Jurnal Skala Husada, 8(2): 119-125.

Fakultas Kedokteraan UI. (2010). Daftar Bahan Makanan Penukar. Jakarta : Balai Penerbit FKUI

Gianfranco Parati et all. (2015). Aging, High Altitude, And Blood Pressure: A Complex Relationship. High Altitude Medicine \& Biology, 16 (2)

Hermina, Prihatini. (2016). Gambaran Konsumsi Sayur dan Buah Penduduk Indonesia dalam Konteks Gizi Seimbang: Analisis Lanjut Survei Konsumsi Makanan Individu ( SKMI ) 2014. Buletin Penelitian Kesehatam, 44(3), 4-10.

Irianto, Koes. 2014. Gizi Seimbang dalam Kesehatan Reproduksi. Bandung: Penerbit Alfabeta

Jufri, A. J. et al. (2015). Perbedaan Tekanan Darah Pada Anak yang Tinggal di Pengunungan dan Tinggal di Tepi Pantai. Jurnal e-Clinic(eCI), 3(1), 452-456. 
Kemenkes. (2014). Buku Studi Diet Total, Survey Konsumsi Makanan Individu Indonesia. Jakarta: Balitbangkes.

Khomsan, Ali. (2003). Pangan dan Gizi Untuk Kesehatan. Jakarta : PT Rajagrafindo Persada

Khouzam, R. N. dan Aziz, R. K. (2009). A Case Report: Can Altitude Change Blood Pressure That Much?. The Journal of Clinical Hypertension, 11(9): 498-499. DOI: 10.1111/j.17517176.2009.00161.x.

Mandang, Q, et al. (2015). Perbandingan tekanan darah antara anak yang tinggal di pegunungan dan pesisir pantai. Jurnal e-Clinic(eCI), 3(1), 1.

Mingji, C. et al. (2015). Relationship between altitude and the prevalence of hypertension in Tibet: a systematic review. Heart, 101(13): 10541060(May) DOI: 10.1136/heartjnl2014-307158.

Nurhumaira, N. S. dan Rahayuningsih, H. M. (2014). Pengaruh Penerapan Pola Diet DASH (distary Approaches To Stop Hypertension) Terhadap Tekanan Darah Sistolik Dan Diastolik pada Kelompok Lansia Di Kota Semarang. Journal Of Nutrition College, 3(4), 554-564. http://ejournals1.undip.ac.id/index.php/jnc.
Pujimulyani, Dwiyati. 2012. Teknologi Pengolahan Sayur-sayuran \& Buahbuahan. Yogyakarta : Graha Ilmu

Rahayuningsih, I. (2010). Hubungan Konsumsi Sayur dan Buah dengan Tekanan Darah Anak Sekolah Dasar. Tesis. Program Studi Ilmu Gizi Fakultas Kedokteran Universitas Diponegoro Semarang.

Rusliafa, J. (2014). Komparatif Kejadian Hipertensi Pada Wilayah Pesisir Pantai dan Pengunungan Di Kota Kendari Tahun 2014. e-Journal Pasca Sarjana Universitas Hasanuddin Makassar.

Sirajuddin, dkk. (2013). Survei Konsumsi Pangan. Jakarta : EGC.

Sukarno, I. A. . (2014). Perbandingan Tekanan Darah Antara Penduduk Yang Tinggal Di Dataran Rendah. Jurnal e-Biomedik, 2(1), 1-8.

WHO. (2012). Increasing fruit and vegetable consumption to reduce the risk of non-communicable disease.

World Food Program (WFP) Indonesia. 2017. Tren Konsumsi dan Produksi Buah dan Sayur. Buletin Pemantauan Ketahanan Pangan Indonesia, Fokus Khusus,

8. 